\title{
PENERAPAN METODE DISKUSI KELOMPOK (BUZZ-GRUP) UNTUK MENINGKATKAN KOMUNIKASI INTERPERSONAL SISWA
}

\author{
Maria Magdalena Tuti Yulianti \\ yulisupriadi65@gmail.com
}

\begin{abstract}
ABSTRAK
Penelitian ini bertujuan untuk meningkatkan komunikasi interpersonal pada siswa kelas XI Multimedia SMK Negeri 8 Bandar Lampung melalui metode diskusi kelompok (Buzz-Grup). Penelitian ini menggunakan pendekatan kuantitatif dengan jenis Penelitian Tindakan Kelas (Classroom Action Research) yang terdiri dari 2 siklus. Setiap siklus mencakup kegiatan perencanaan, pelaksanaan, observasi, dan refleksi. Subjek penelitian adalah 30 siswa kelas XI Multimedia SMK Negeri 8 Bandar Lampung. Sumber data dalam penelitian ini berasal dari guru dan siswa. Pengambilan data dalam penelitian ini melalui observasi, wawancara, dokumentasi, dan skala komunikasi interpersonal. Validitas data yang digunakan melalui validasi konstrak. Analisi data menggunakan diskriptif kuantitatif. Hasil penelitian menunjukkan adanya peningkatan komunikasi interpersonal melalui metode diskusi kelompok (Buzz-Grup) pada siswa XI Multimedia SMK Negeri 8 Bandar Lampung. Peningkatan dapat dilihat pada kondisi awal hanya terdapat 9 siswa atau 30\% yang memperoleh skor di atas 72 atau dinyatakan tuntas belajar. Pada siklus I meningkatkan menjadi 25 siswa atau 83,33\% siswa yang dinyatakan tuntas dengan terdiri dari 9 siswa atau 30\% dalam ketegori baik dan 16 siswa atau 53,33\% dalam kategori sedang. Pada siklus kedua, 100\% siswa atau $30 \%$ siswa dinyatakan tuntas terdiri dari 23 siswa atau 76,67\% dalam kategori baik dan 7 siswa atau $23,33 \%$ dalam ketegori sedang.
\end{abstract}

Kata kunci: komunikasi interpersonal, diskusi kelompok (Buzz-Grup)

\section{PENDAHULUAN}

Proses komunikasi tidak selamanya dapat berjalan lancar. Setiap individu memiliki kemampuan bersosialisai yang berbeda, kemampuan komunikasi dipengaruhi oleh latar belakang kehidupan yang berbeda, baik dari segi pendidikan orang tua, pendidikan formal, gaya hidup, ekonomi, lingkungan tempat tinggal maupun kesehatan, sehingga perbedaan tersebut sering menghambat proses komunikasi antar individu. Apabila individu mampu menciptakan iklim komunikasi secara efektif, maka individu tersebut tidak akan kesulitan menjalin komunikasi interpersonal, baik dilingkungan keluarga, lingkungan masyarakat, dan lingkungan sekolah. 
Komunikasi interpersonal menurut Hardjana (2003:85) merupakan interaksi tatap muka antara dua atau lebih, dimana pengirim dapat menyampaikan pesan secara langsung, dan penerima pesan dapat menerima dan menanggapi secara langsung. Menurut Liliweri (2011:47) Komunikasi Interpersonal bercirikan : 1. Arus pesan dua arah, 2. Konteks komunikasi adalah tatap muka, 3. Tingkat Umpan balik yang tinggi, 4. Kemampuan untuk mengatasi selektivitas yang tinggi, 5. Kecepatan menjangkauk yang terjadi sasaran yang besar. 6. Efek yang terjadi antara lain perubahan sikap.

Dalam buku riset Sumber Daya dalam Organisasi(Husein Umur, 1998:26) menjelaskan bahwa sekarang terdapat beberapa aspek yang penting dalam kefektifan komunikasi, yaitu: a). Keterbukaan, b). Empati mencoba merasakan perasaan yang dirasakan lwan bicara, c). Dukungan, d). Kepositifan, e). Rasa Kesamaan.

Diskusi Kelompok menurut Sudjana S. Djuju mengatakan bahwa pembicaraan melalui tatap muka yang direncanakan dianyata siswa mengenai topik bahasan tertentu dan dipimpin oleh pemimpin diskusi. Romlah (2006: 89) juga menjelaskan bahwa diskusi kelompok adalah percakapan yang sudah direncanakan antara 3 orang atau lebih dengan tujuan untuk memecahkan masalah atau suatu persoala, dibawah pimpinan seorang pemimpin. Jacobsen Eggen, Kauchak, dan Dulaney (Romlah, 2006: 89) manyatakan bahwa diskusi kelompok dapat digunakan dengan beberapa tujuan yaitu : 1. Mengembangkan keterampilan kepemimpian, 2. Merangkum pendapat ahli, 3. Guna mencapai persetujuan kelompok, 4. Belajar menjadi pendengar yang aktif. 5. Mengatasi berbagi pendapat dengan tepat, dan 6. Mengembangkan kemampuan menganalisis, mensistensi dan nilai. Buzz-Grup (kelompok kecil) menurut Hasibuan dan Sulthoni (2000:65) adalah suatu proses percakapan yang teratur dan sistematis, melibatkan sekelompok orang dalam interaksi tatap muka yang bebas dan terbuka, dengan tujuan berbagi informasi atau pengalaman, megambil keputusan atau memecahkan suatu masalah.

Komunikasi Interpersonal menurut Rakhmat (2005: 129-136) adalah komunikasi yang memiliki rasa percaya pada orang lain, sikap suportif, dan terbuka.Situasi yang diperlukan untuk mengembangkan komunikasi interpersonal adalah situasi komunikasi yang mendalam dan terjadi dalam waktu yang cukup lama. Hal ini sesuai 
dengan tujuan diskusi kelompok untuk mengembangkan pandangan baru mengenai hubungan antar individu.Diharapkan melalui Buzz-Group ini siswa dapat belajar bersama dalam memcahkan masalah, melalui diskusi kelompok yang dapat bertukar pikiran, pendapat, argument dan pengalaman. Berdasarkan permasalahan yang terjadi dilapangan, penelitian ini berasumsi komunikasi interpersonal pada siswa dapat dikembangkan terutama pada siswa kelas XI Multimedia SMK Negeri 8 Bandar Lampung. Pengembangan komunikasi ini dilakukan dengan metode Buzz-Grup, sehingga siswa diharapkan mampu memecahkan masalah dan saling bertukar pengalaman.

Tujuan peneliti melakukan penelitian ini adalah diharapkan penggunaan metode diskusi kecil (Buzz-Grup) dapat meningkatkan komunikasi interpersonal para siswa kelas XI Multimedia SMK Negeri 8 Bandar Lampung dalam rangka peningkatan ketuntatasan belajar siswa tersebut.

\section{METODE}

Penelitian ini menggunakan metode penelitian tindakan kelas. Menurut Suharsimi Arikunto, dkk (2007:3) penelitian tindakan kelas merupakan suatu pencermatan terhadap kegiatan belajar berupa sebuah tindakan, yang sengaja dimunculkan dan terjadi dalam sebuah kelas secara bersaman. Fokus penelitian ini terletak pada tindakan-tindakan alternative yang dibuat oleh peneliti, kemudian diujicobakan dan dievaluasi apakah tindakan tersebut dapat memecahkan permasalahan yang dihadapi oleh siswa kelas XI Multimedia SMK Negeri 8 Bandar Lampung.Metode yang peneliti lakukan dalam penelitian ini adalah dengan menggunakan Buzz-Grup guna mengupayakan peningkatan keterampilan komunikasi interpersonal para siswa tersebut.

Penelitian ini dilaksanakan selama 3 bulan, dimulai dari bulan September sampai dengan bulan Nopember 2015. Penelitian ini diberikan kepada siswa kelas XI MM-1 tahun pelajaran 2015/2016 yang berjumlah 30 siswa $(\mathrm{L}=21$ siswa, $\mathrm{P}=9$ siswa). Model penelitian yang digunakan adalah model Kemmis \& McTaggart, yaitu model pengembangan dari konsep dasar yang diperkenalkan oleh Kurt. Hanya saja 
komponen actng (tindakan) dengan observing (pengamatan) disatukan.Model Kemmis \& McTaggart pada hakikatnya berupa prangkat atau untaian dengan satu perangkat terdiri dari empat komponen, yaitu Perencanaan, Tindakan, Pengamatan, dan Refleksi.Keempat komponen yang berupa untaian tersebut dipandang sebagai satu sikulus. Penelitian ini melakukan teknik dan instrumen Pengumpulan data dengan sebagai berikut :

\section{- Observasi}

Observasi menurut Arikunto (2007:133) observasi merupakan suatu kegaiatan pembuatan terhadap sesuatu objek dengan melibatkan seluruh alat indra. Aspek yang diobservasi dalam Diskusi Buzz-Grup yaitu : 1. Perencanaan dalam persiapan materi diskusi, alat dan bahan diskusi, serta pembentukan kelompok diskusi Buzz-Grup, 2. Dalam pelaksanaan semua siswa ikut diskusi, siswa dapat menyampaikan pendapat, dan siswa saling percaya dan mampu mengatasi masalah, 3. Kemudian hasil pelaksanaan.

\section{- Wawancara}

Menurut Sugiyono (2010:194) berpendapat bahwa wawancara digunakan sebagai teknik pengumpulan data apabila peneliti ingin melakukan stdi pendahuluan untuk menemukan yang harus diteliti.Dalam penelitian ini wawancara ditunjukan kepada guru bimbingn dan konseling siswa untuk mengetahui komunikasi interpersonal siswa sebelum dan sesudah dilakukan tindakan. Penelitian ini menggunakan pedoman sebagai berikut :

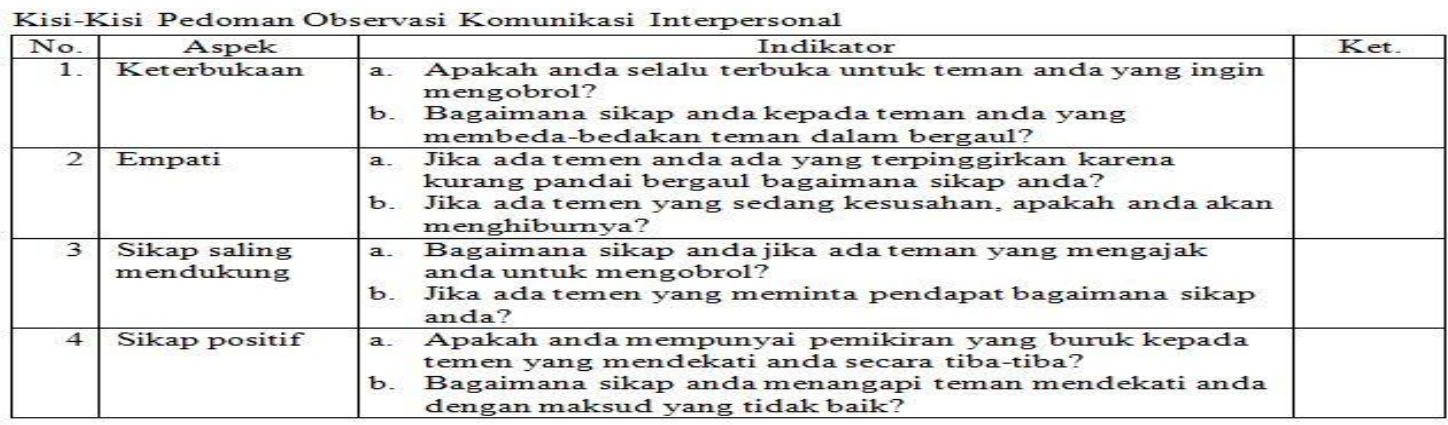

Pedoman Wawancara diskusi Buzz-Grup untuk Subjek

\begin{tabular}{|r|l|l|}
\hline No. & \multicolumn{1}{|c|}{ Pertanyaan } & Jawaban Subjek \\
\hline 1. & $\begin{array}{l}\text { Bagaimana perasaan siswa setelah mengikuti diskusi } \\
\text { Buzz-Grup? }\end{array}$ & $\begin{array}{l}\text { Apakah siswa memahami makna dari diskusi Buzz-Grup } \\
\text { yang diikuti? }\end{array}$ \\
\hline 3. & $\begin{array}{l}\text { Manfaat apa yang diperoleh setelah mengikuti diskusi } \\
\text { Buzz-Grup? }\end{array}$ & $\begin{array}{l}\text { Perubahan apa yang dirasakan oleh siswa setelah } \\
\text { mengikuti tindakan? }\end{array}$ \\
\hline 4.
\end{tabular}


- Dokumentasi

Dokumentasi digunkan sebagai bagian dalam penelitian tindakan ini.Dokumen tersebut berupa data yang mendukung penelitian.

Teknik analisis data yang digunakan dalam penelitian ini adalah analisis deskriptif kuantitatif, dengan menggunakan rumus rata-rata dengan teknik tabulasi data secara kuantitatif berdasarkan hasil tindakan.

Kategori Kriteria Keberhasilan

\begin{tabular}{|r|c|c|}
\hline No. & Rentang Skor & Kategori \\
\hline 1. & $108 \geq \mathrm{X}$ & Tinggi \\
\hline 2. & $72 \leq \mathrm{X}<108$ & Sedang \\
\hline 3. & $\mathrm{X}<72$ & Rendah \\
\hline
\end{tabular}

Dari table di atas dapat dijelaskan komunikasi interpersonal dianggap rendah bila skor kurangdari 72 poin, sedang bila point lebih dari dari 72 tapi masih dibawah 108 point, dan tinggi bila point diatas 108 point.

Keberhasilan Penelitian ini apabila diperoleh hasil sebagai berikut :

1. Siswa dapat meningkatkan komunikasi interpersonal melalui metode Buzz-Grup,

2. Skor komunikasi interpersonal sudah 72 point ke atas atau di rentang sedang,

3. Ketuntasan siswa minimal $85 \%$.

\section{HASIL PENELITIAN DAN PEMBAHASAN}

Sebelum melakukan penelitian, terlebih dahulu dilakukan observasi, wawancara dan pre-test awal terhadap siswa kelas XI MM-1 SMK Negeri 8 Bandar Lampung, dengan kondisi sebagai berikut :

Hasil Prestest Pra Sikulus

\begin{tabular}{|c|c|c|c|c|}
\hline Rentang skor & Kategoni & Jumlah siswa & $\%$ & Ket. \\
\hline $108 \geq X$ & Tinggi & 0 & 0 & TUNTAS \\
\hline $72 \leq X<108$ & Sedang & 9 & 30 & TUNTAS \\
\hline$X<72$ & Rendah & 21 & 70 & BELUMTUNTAS \\
\hline & 30 & 100 & \\
\hline
\end{tabular}


Dari data tersebut dapat dilihat bahwa kebanyakan siswa yang memiliki maslaah komunikasi interpersonal sebanyak 21 siswa atau 70\% dari keseluruhan jumlah siswa kelas XI MM-1 SMK Negeri 8 Bandar Lampung. Kemudian dilakukan tindakan tahap 1 berdasarkan siklus-siklus yang dijelaskan sebelumnya yang memperoleh hasil sebagai berikut :

Hasil Post-test 1

\begin{tabular}{|c|c|c|c|c|}
\hline Rentang skor & Kategori & Jumlah siswa & $\%$ & Ket. \\
\hline $108 \geq X$ & Tinggi & 9 & 30 & TUNTAS \\
\hline $72 \leq X<108$ & Sedang & 16 & 53,3 & TUNTAS \\
\hline$X<72$ & Rendah & 5 & 16,7 & BELUMTUNTAS \\
\hline & 30 & 100 & \\
\hline
\end{tabular}

Tabel diatas menunjukan dari 30 siswa terdapat 16 siswa kriteria sedang, 9 siswa tinggi, namun masih ada 5 siswa yang berkriteria rendah. Dapat disimpulkan pada observari tahap 1 ini penerapan Buzz-Grup untuk meningkatkan komunikasi interpersonal berjalan lancar. Selanjutnya dilakukan post-test 2, dengan maksud untuk memperkuat data hasil observasiselama tindakan berlangsung.Hal ini juga untuk mengetahui ada atau tidaknya peningkatan yang terjadi setelah dilakukan siklus 1 dan siklus 2 . Hasil dari post-test 2 adalah sebagai berikut :

\section{Hasil Post-test 2}

\begin{tabular}{|c|c|c|c|c|}
\hline Rentang skor & Kategon' & Jumlah siswa & $\%$ & Ket. \\
\hline $108 \geq X$ & Tinggi & 23 & 76,7 & TUNTAS \\
\hline $72 \leq X<108$ & Sedang & 7 & 23,3 & TUNTAS \\
\hline$X<72$ & Rendah & 0 & 0 & BELUMTUNTAS \\
\hline & 30 & 100 & \\
\hline
\end{tabular}

Dari data tersebut dapat disimpulkan bahwa 7 siswa berkriteria sedang, dan 23 siswa berkriteria tinggi. Hasil ini menunjukan peningkatan dari post-test 1 yang hanya 9 siswa yang memiliki kriteria tinggi, 16 siswa sedang, dan 5 siswa berkriteria rendah. Data ini juga menunjukkan bahwa tidak ditemukan siswa yang memiliki komunikasi 
interpersonal yang rendah, sehingga proses perbaikan pembelajaran dinyatakan Tuntas, dan berhasil pada siklus ke dua.

Berdasarakan observasi yang dilakukan pada siswa kelas XI MM-1 SMK Negeri 8 Bandar Lampung cenderung melakukan kesalahpahaman dalam berkomunikasi, mereka sering bertentangan satu sama lain di dalam pelajaran maupun saat di luar jam pelajaran. Sebagian besar siswa kesulitan dalam berkomunikasi dengan berbagai alasan.Hal tersebut terlihat dalam hasil observasi dan hasil skala pra siklus yang menunjukkan bahwa dari 30 siswa terdapat 21 siswa yang memiliki skor rendah dalam skala komunikasi interpersonal.Masalah ini berusaha diperbaiki dengan metode yang tepat.

Kemudian dilakukan metode diskusi kelompok sesuai dengan teori Arends (Helly \& Sri, 2008:95-96) yaitu membagi siswa menjadi kelompok kecil (Buzz-Grup) dengan anggota 5-6 orang.Siswa diberi waktu berdiskusi dengan kelompoknya, dan diakhir diskusi perwakilan tiap kelompok diminta melakukan presentasi hasil diskusi kecil tersebut.Metode Buzz-Grup memberikan pengalaman berkomunikasi kepada seluruh anggota kelompok dan saling mendapat umpan balik secara langsung dari seluruh anggota sehingga komunikasi interpersonal dapat meningkat.Siswa terlihat sangat antusias selama dilakukan metode pembelajaran tersebut. Metode Buzz-Grup memilik peran penting bagi guru Bimbingan dan Konseling.Guru BK dituntut untuk memiliki kreatifitas untuk menyajikan diskusi kelompok kecil dengan lebih menarik sehingga siswa tidak mudah merasa bosan.Metode Buzz-Grup dapat memudahkan guru BK dalam mengamati perilaku dan kecakapan dalam berkomunikasi.Hasil dari penelitian ini dapat menggambarkan baha tujuan dialakukan penelitian ini telah tercapai yaitu dengan meningkatkan tingkat komunikasi interpersonal siswa kelas XI MM-1 SMK Negeri 8 Bandar Lampung melalui diskusi Buzz-Grup.

\section{KESIMPULAN}

Berdasarkan hasil penelitian ini, dapat disimpulkan bahwa dengan menggunakan metode Buzz-Grup dapat meningkatkan komunikasi interpersonal pada siswa kelas XI MM-1 SMK Negeri 8 Bandar Lampung. 


\section{DAFTAR PUSTAKA}

Agus M. Hardjana. 2003. Komunikasi Intrapersonal dan Interpersonal. Yogyakarta: Kanisius.

Alo R. Liliweri. 1991. Komunikasi Serba Makna. Jakarta: Kencana.

Arends, Richard I. 2008. Learning to Teach (alih bahasa; Helly Prajitno S dan Sri Mulyantini S). Yogyakarta: Pustaka Pelajar.

Arni Muhammad. 2007. Komunikasi Organisasi. Jakarta: PT. Bumi Aksara.

Devito, J.A. 2007. Komunikasi Antar Manusia (alih bahasa: Agus Maulana). Jakarta: Professional Books.

Dian Wisnuwardhani dan Sri Fatmawati Mashoedi. 2012. Hubungan Interpersonal. Jakarta: Salemba Humanika.

Emzir.2010. Metodelogi Penelitian Pendidikan Kuantitatif dan Kualitatif. Jakarta: Rajawali Post.

Endang Poerwanti dan Nur Widodo. 2002. Perkembangan Psikologi. Malang: UMM Press.

Goldberg. Alvin A. dan Larson, Carl E. 2006. Komunikasi Kelompok: Proses Diskusi dan Penerapannya (alih bahasa: Koesdarini Soemiati dan Gary R. Jusuf). Jakarta: UI Press.

Hurlock, Elizabeth B. 1980. Psikologi Perkembangan (alih bahasa: Istiwidayanti dan Soedjarwo). Jakarta: Erlangga.

J.J Hasibuan dan Sulthoni. 2000. Kemampuan Dasar Mengejar. Malang: Universitas Negeri Malang Press.

Jalaluddin Rahmad. 2005. Psikologi Komuikasi. Bandung: PT. Remaja Rosdakarya.

Jhon W. Santrock. 2003. Adolescence : Perkembangan Remaja (alih bahasa: Sintho B. Adelar). Jakarta: Erlangga.

Mohammad Ali, dkk. 2006. Psikologi Remaja. Bandung: Remaja Rosdakarya.

Muh.Nazir. 2005. Metode Penelitian. Bogor: Ghalia Indonesia.

Nana Sudjana dan Ahmad Rafai. 2005. Media Pengajar. Bandung: Sinar Baru.

Roestiyah N.K. 2001. Strategi Belajar Mengajar. Jakarta: Rineka Cipta PT Asti Mahasatsa.

Singgih D. Gunarsa dan Yulia Singgih. 1991. Psikologi Anak. Jakarta: Gunung Mulia.

Sitti Hartinah. 2009. Konsep dasar Bimbingan Kelompok. Bandung; PT Refika Aditama.

Sri Rumini dan Siti Sundari.2004. Perkembangan Anak dan Remaja.Jakarta; Rineka Cipta.

Sudjana S. Djuju. 2005. Metode dan Teknik Pembelajaran Partisipatif. Bandung: Falah Production.

Sugiyono. 2010. Memahami Penelitian Kualitatif. Bandung: Alpabeta.

Suharsimi Arikunto, dkk, 2007. Penelitian Tindak Kelas. Jakarta: Bumi Aksara.

Suranto Aw. 2011. Komunikasi Interpersonal. Yogyakarta: Graha Ilmu.

Suryosubroto. 2002. Proses Belajar Mengajar di Sekolah. Jakarta: PT. Rineka Cipta. 
Syamsu Yusuf. 2006. Psikologi Perkembangan Anak dan Remaja. Bandung: PT. Remaja Rosdakarya.

Tatiek Romlah. 2006. Teori dan Praktek Bimbingan Kelompok. Malang: Universitas Negeri Malang Press. 